Original article

\title{
Evaluation of cardiovascular risk factors among university students in Turkey: a cross-sectional survey
}

\author{
Rasim Kutlu, Mehmet Erdem Memetoglu
}

Gümüşhane State Hospital, Gümüşhane, Turkey

Siyami Ersek Educating and Training Hospital, Istanbul, Turkey

Received 20 May 2013, Accepted 18 June 2013

(C) 2013, Kutlu R., Memetoglu M.E.

(C) 2013, Russian Open Medical Journal

\begin{abstract}
Background - Recent data indicate increasing rates of mortality from cardiovascular (CV) disease in Turkey. This study aimed to evaluate $\mathrm{CV}$ disease risk factors among university students in Northern Turkey.

Methods - In this cross sectional descriptive study, 302 students were randomly recruited (171 females (57\%) and 131 males (43\%), mean age of $20 \pm 2.1$ years). Blood glucose, cholesterol profile (total, high density lipoprotein (HDL) and low density lipoprotein (LDL) cholesterols), triglyceride, glycosylated haemoglobin, resting blood pressure, and body mass index were measured using standard protocols. All participants were asked to complete a questionnaire including questions on lifestyle, genetic predisposition, smoking habit, and psychosocial factors.

Results - The mean systolic and diastolic blood pressure of students were $127.1 \pm 13.5 \mathrm{mmHg}$ and $78.3 \pm 12.4 \mathrm{mmHg}$. The mean values were $98.4 \pm 14.2 \mathrm{mg} / \mathrm{dL}$ for fasting blood glucose value, $5.4 \pm 0.4$ for $\mathrm{HbA}_{1 \mathrm{c}}, 80.0 \pm 10.3$ beats $/ \mathrm{min}$ for heart rate, for total cholesterol $199.1 \pm 24.6$ $\mathrm{mg} / \mathrm{dL}, 43.8 \pm 9.9 \mathrm{mg} / \mathrm{dL}$ for $\mathrm{HDL}, 114.7 \pm 24.1 \mathrm{mg} / \mathrm{dL}$ for $\mathrm{LDL}, 199.1 \pm 24.6 \mathrm{mg} / \mathrm{dL}$ for trygliceride, $24.8 \pm 3.6 \mathrm{~kg} / \mathrm{m}^{2}$ for body mass index, $97.6 \pm 17.9 \mathrm{~cm}$ for waist circumference. No significant difference was observed between gender according to CV risk factors' values statistically. It was observed that $111(36.8 \%)$ students were overweight, 32 (10.6\%) were obes. About 135 (44.0\%) of students had abnormally unacceptable WC value. Smoking habit was seen in $130(43.0 \%)$ students [73 (24.2\%) male and $57(18.9 \%)$ female].

Conclusion - A substantial proportion of Turkish students were overweight or obese, and had smoking habit. Our results underscore the need to implement health promotion programmes and perform large-scale epidemiological studies within the general Turkish young adult population.
\end{abstract}

Keywords: cardiovascular disease, risk factors, university, students

Cite as Kutlu R, Memetoglu ME. Evaluation of cardiovascular risk factors among university students in Turkey: a cross-sectional survey. Russian Open Medical Journal 2013; 2: 0307

Correspondence to Rasim Kutlu. Address: Gümüşhane State Hospital, Department of Cardiology, Gümüşhane, Turkey. E-mail: dr.rasim@mail.ru Phone: +90 4562131556 . Fax: +90 4562134346.

\section{Introduction}

Cardiovascular (CV) diseases are the leading cause of mortality and morbidity in the world even in the developing countries [1]. The manifestations of the diseases increase in middle-aged adults, however, many studies reported signs of atherosclerotic pathogenesis in younger adults and children as young as 5-6 years old [2-4].

The finding that atherosclerotic disease begins at an early stage of life reveals childhood and adolescence as critical periods for the detection of risk factors for CV disease and the prevention of future complications. Monitoring these factors would help identify early signs that when modifed can mitigate or even reverse the progression of those dysfunctions. A range of risk factors, including genetic factors, hypertension, dyslipidemia, obesity, metabolic syndrome (MS), an atherogenic diet, and physical inactivity, is associated with CV disease, and the prevalence of these factors is increasing among children and adolescents $[5,6]$.
In this study, we reported the prevalence of $\mathrm{CV}$ disease risk factors among university students in Turkey.

\section{Material and Methods}

\section{Study population}

Three hundred eighty students attending the University of Gümüşhane (Gümüşhane, Turkey) were randomly selected, and invited to participate in the study. 302 students (171 females (57\%) and 131 males (43\%), mean age of $20 \pm 2.1$ years) voluntarily accepted the invitation. Written consent to participate was obtained before data collection. All participants were asked to complete a questionnaire assessing CV risk factors (genetic predisposition, smoking habit, and psychosocial factors). The anthropometric, body composition, blood pressure measurement, and laboratory tests were performed on all subjects in Cardiology Department. The study was approved by the local ethics committee.

To measure resting blood pressure, subjects were seated in a semireclined position with arms relaxed and supported and with 
the mid point of the upper arm at the level of the heart. After a resting period of at least 5 minutes, blood pressure was measured with a mercury manometer (Riester, Jungingen, Germany).

Reference ranges in the study were for total cholesterol (TC) $>5.0 \mathrm{mmol} / \mathrm{L} \quad(190 \mathrm{mg} / \mathrm{dL})$; low density lipoprotein (LDL) $>3.0 \mathrm{mmol} / \mathrm{L}(115 \mathrm{mg} / \mathrm{dL})$; high density lipoprotein (HDL) $<1.0$ $\mathrm{mmol} / \mathrm{L}(40 \mathrm{mg} / \mathrm{dL}$ ) for male and $<1.2 \mathrm{mmol} / \mathrm{L}(46 \mathrm{mg} / \mathrm{dL})$ for female; triglyceride (TG) $>1.7 \mathrm{mmol} / \mathrm{L}(150 \mathrm{mg} / \mathrm{dL})$; fasting plasma glucose level for healthy inviduals $5.5-6.9 \mathrm{mmol} / \mathrm{L}(100-125$ $\mathrm{mg} / \mathrm{dL}) ;$ glycosylated haemoglobin $\left(\mathrm{HbA}_{1 \mathrm{c}}\right) \quad 7.0-7.9 \% \quad(53-63$ $\mathrm{mmol} / \mathrm{L}$ ) [7].

Reference values for blood pressure that we have included in the study were based on 'Society of Hypertension World Health Organisation' (WHO-HT) values [7].

The weight and height of students were measured, and the associated body mass index (BMI) was calculated. The reference values participated in the study for BMI were categorised as poor weight $\left(<18.5 \mathrm{~kg} / \mathrm{m}^{2}\right)$, normal $\left(18.5-24.9 \mathrm{~kg} / \mathrm{m}^{2}\right)$, overweight (25$\left.29.9 \mathrm{~kg} / \mathrm{m}^{2}\right)$, and obese $\left(\geq 30 \mathrm{~kg} / \mathrm{m}^{2}\right)[7]$.

Students' waist circumferences (WCs) were measured. WC was measured to the nearest $0.1 \mathrm{~cm}$, directly on the landmarked skin with a flexible, inelastic measuring tape with a tension meter attached, he measure is taken at the highest point of the iliac crest [8]. Reference WC value for men was $102 \mathrm{~cm}$, and for females was $88 \mathrm{~cm}$ [7].

Blood samples were drawn from the antecubital vein by careful venipuncture using a 21-gauge needle attached to sterile syringe without stasis at 8.00 to $10.00 \mathrm{AM}$, after a fasting period of 12 hours. Participants' lipid levels, fasting blood glucose and $\mathrm{HbA1c}$ levels were measured. The standard 12 lead electrocardiogram (ECG) was carried out for all participants who have at least one risk factor.

\section{Statistical Analysis}

All statistical data were obtained from the "Microsoft Office Excel 2007" and analyzed with "Statistica 10" programs. Nonparametric criteria was used for comparisons between groups statistically. The Wilcoxon Matched Pairs Signed Ranks Test was used to determine the magnitude of difference between matched groups. For statistical analysis, non-normally distributed data were analyzed with Mann-Whitney U-test (for two-group comparison. The Correlation Coefficient (Pearson's r) Formula was used to analyze and determine the correlation coefficient between groups. $P$ values smaller than 0.05 were accepted significant statistically.

\section{Results}

Type 1 diabetes mellitus was seen in $2(0.7 \%)$ participants. Secondary hypertension was seen in $1(0.4 \%)$ participant. The dispersion of cardiovascular risk factors among university students according to gender is shown in Table 1.

No significant difference was observed between genders according to cardiovascular risk factors' values statistically (Table 1).

The mean systolic and diastolic blood pressures of students were $127.1 \pm 13.5 \mathrm{mmHg}$ and $78.3 \pm 12.4 \mathrm{mmHg}$. The mean values were $98.4 \pm 14.2 \mathrm{mg} / \mathrm{dL}$ for fasting blood glucose value, $5.4 \pm 0.4$ for $\mathrm{HbA}_{1 \mathrm{c}}, 80.0 \pm 10.3$ beats/min for heart rate, for total cholesterol $199.1 \pm 24.6 \mathrm{mg} / \mathrm{dL}, 43.8 \pm 9.9 \mathrm{mg} / \mathrm{dL}$ for $\mathrm{HDL}, 114.7 \pm 24.1 \mathrm{mg} / \mathrm{dL}$ for $\mathrm{LDL}, 199.1 \pm 24.6 \mathrm{mg} / \mathrm{dL}$ for trygliceride, $24.8 \pm 3.6 \mathrm{~kg} / \mathrm{m}^{2}$ for $\mathrm{BMI}$, $97.6 \pm 17.9$ for WC.

The mean trygliceride value for males was $200.1 \pm 25.2 \mathrm{mg} / \mathrm{dL}$, and $197.8 \pm 24.0 \mathrm{mg} / \mathrm{dL}$ for females. Mean WC value for males was $101.6 \pm 16.6 \mathrm{~cm}$, and $94.4 \pm 18.2$ for females.

The distribution of cardiovascular risk factors' values (\%) between genders is shown in Table 2 . The number of participants with fasting blood glucose values $\geq 126 \mathrm{mg} / \mathrm{dL}$ was 9 (3.0\%), (2 $(0.7 \%)$ male and 7 (2.2\%) female). There was one male participant (0.3\%) with type I diabetes mellitus whose $\mathrm{HbA}_{1 \mathrm{C}}$ value $\geq 8.0$.

According to Table 2, it was observed that 111 (36.8\%) students were overweight, 32 (10.6\%) were obes. About 135 (44\%) of students had abnormally unacceptable WC value. The distribution of cardiovascular risk factors' ratios (\%) between genders is shown in Table 3.

In females, number of patients with heart rate $\geq 90$ beats $/ \mathrm{min}$ (8.6\%), having total cholesterol value $\geq 190 \mathrm{mg} / \mathrm{dl}(22.5 \%), \mathrm{HDL} \leq$ $39 \mathrm{mg} / \mathrm{dl}(26.2 \%)$, triglyceride $\geq 150 \mathrm{mg} / \mathrm{dl}(12.3 \%)$, BMI $25.0-29.9$ $(20.9 \%)$, waist circumference $\leq 88 \mathrm{~cm}(30.5 \%)$, systolic blood pressure $\geq 140 \mathrm{mmHg}(8.6 \%)$, diastolic blood pressure $\geq 90 \mathrm{mmHg}$ (9.0\%), genetic predisposition (20.5\%), sedentary life style (27.8\%), overweight (20.9\%), obesity (6.3\%), abdominal obesity (26.2\%), and hyperglycemia (2.3\%) were higher than males.

Smoking habit was seen in $130(43.0 \%)$ students [73 (24.2\%) male, 57 (18.9\%) female].

In males, number of patients having waist circumference value $89-102(15.2 \%) \mathrm{cm}$, and $>102 \mathrm{~cm}(18.5 \%)$, and smoking habit (24.2\%) were higher than females.

Table 1.The distribution of cardiovascular risk factors' mean values between genders (mean $\pm S D$ )

\begin{tabular}{|c|c|c|c|c|}
\hline \multirow[b]{2}{*}{ Risk Factors } & \multirow{2}{*}{ Total $(n=302)$} & \multicolumn{2}{|c|}{ Gender } & \multirow{2}{*}{ P-level } \\
\hline & & Male $(n=131)$ & Female $(n=171)$ & \\
\hline Age (years) & $20.3 \pm 2.1$ & $20.3 \pm 2.2$ & $20.2 \pm 2.1$ & $>0.05$ \\
\hline Glucose (mg/dL) & $98.4 \pm 14.2$ & $97.0 \pm 8.7$ & $99.4 \pm 17.2$ & $>0.05$ \\
\hline $\mathrm{HbA}_{1 \mathrm{c}}(\%)$ & $5.4 \pm 0.4$ & $5.3 \pm 0.3$ & $5.4 \pm 0.4$ & $>0.05$ \\
\hline Heart rate (bpm) & $80.0 \pm 10.3$ & $80.3 \pm 9.7$ & $79.7 \pm 10.8$ & $>0.05$ \\
\hline Total cholesterol (mg/dL) & $199.1 \pm 24.6$ & $200.1 \pm 25.2$ & $197.8 \pm 24.0$ & $>0.05$ \\
\hline $\mathrm{HDL}(\mathrm{mg} / \mathrm{dL})$ & $43.8 \pm 9.9$ & $43.1 \pm 10.2$ & $44.4 \pm 10.0$ & $>0.05$ \\
\hline $\mathrm{LDL}(\mathrm{mg} / \mathrm{dL})$ & $114.7 \pm 24.1$ & $114.3 \pm 25.5$ & $115.0 \pm 23.0$ & $>0.05$ \\
\hline $\mathrm{TG}(\mathrm{mg} / \mathrm{dL})$ & $185.2 \pm 37.9$ & $188.1 \pm 41.9$ & $183.0 \pm 34.3$ & $>0.05$ \\
\hline BMi $\left(\mathrm{kg} / \mathrm{m}^{2}\right)$ & $24.8 \pm 3.6$ & $24.6 \pm 3.6$ & $24.9 \pm 3.6$ & $>0.05$ \\
\hline Waist Circumference $(\mathrm{cm})$ & $97.6 \pm 17.9$ & $101.6 \pm 16.6$ & $94.4 \pm 18.2$ & $>0.05$ \\
\hline Systolic blood pressure (mmHg) & $127.1 \pm 13.5$ & $127.1 \pm 12.5$ & $127.2 \pm 14.3$ & $>0.05$ \\
\hline Diastolic blood pressure $(\mathrm{mmHg})$ & $78.3 \pm 12.4$ & $77.6 \pm 12.0$ & $79.0 \pm 13.0$ & $>0.05$ \\
\hline
\end{tabular}

TG is triglyceride; $\mathrm{HDL}$ is high density lipoprotein; $\mathrm{LDL}$ is low density lipoprotein; $\mathrm{BMI}$ is body mass index; $\mathrm{HbA}_{1 \mathrm{c}}$ is glycated hemoglobin. 
Cardiology

Table 2. The distribution of cardiovascular risk factors' values between genders

\begin{tabular}{|c|c|c|c|c|}
\hline \multirow{2}{*}{ Risk Factors } & \multirow{2}{*}{ Total $(n=302)$} & \multicolumn{2}{|c|}{ Gender } & \multirow{2}{*}{ P-level } \\
\hline & & Male $(n=131)$ & Female $(n=171)$ & \\
\hline \multicolumn{5}{|c|}{ Glucose (mg/dL) } \\
\hline$\leq 99$ & 207 (68.5\%) & $95(31,5 \%)$ & $112(37.1 \%)$ & $>0.05$ \\
\hline $100-125$ & $86(28.5 \%)$ & $34(11.3 \%)$ & $52(17.2 \%)$ & $>0.05$ \\
\hline$\geq 126$ & $9(3.0 \%)$ & $2(0.7 \%)$ & $7(2.2 \%)$ & $>0.05$ \\
\hline \multicolumn{5}{|l|}{$\operatorname{HbA1C}(\%)$} \\
\hline$\leq 6.9$ & $298(98.7 \%)$ & $129(42.7 \%)$ & $169(56.0 \%)$ & $<0.05$ \\
\hline 7.0-7.9 & $3(1.0 \%)$ & $1(0.3 \%)$ & $2(0.7 \%)$ & $>0.05$ \\
\hline$\geq 8.0$ & $1(0.3 \%)$ & $1(0.3 \%)$ & $0(0 \%)$ & - \\
\hline \multicolumn{5}{|c|}{ Heart rate $(\mathrm{bpm})$} \\
\hline$\leq 59$ & $12(4.0 \%)$ & $6(2.0 \%)$ & $6(2.0 \%)$ & $>0.05$ \\
\hline $60-89$ & $246(82.4 \%)$ & $107(35.4 \%)$ & $139(46.0 \%)$ & $<0.05$ \\
\hline$\geq 90$ & $44(13.6 \%)$ & $18(6.0 \%)$ & $26(8.6 \%)$ & $>0.05$ \\
\hline \multicolumn{5}{|c|}{ Total cholesterol $(\mathrm{mg} / \mathrm{dL})$} \\
\hline$\leq 189$ & $203(67.2 \%)$ & $100(33.1 \%)$ & $103(34.1 \%)$ & $>0.05$ \\
\hline$\geq 190$ & $99(32.8 \%)$ & $31(10.3 \%)$ & $68(22.5 \%)$ & $<0.05$ \\
\hline \multicolumn{5}{|l|}{$H D L(m g / d L)$} \\
\hline$\leq 39$ & $139(46.0 \%)$ & $60(19.9 \%)$ & $79(26.2 \%)$ & $>0.05$ \\
\hline $40-46$ & $41(13.6 \%)$ & $19(6.3 \%)$ & $22(7.3 \%)$ & $>0.05$ \\
\hline$\geq 47$ & $122(40.4 \%)$ & $52(17.2 \%)$ & $70(23.1 \%)$ & $<0.05$ \\
\hline \multicolumn{5}{|l|}{$L D L(\mathrm{mg} / \mathrm{dL})$} \\
\hline$\leq 114$ & $253(83.8 \%)$ & $110(36.4 \%)$ & $143(47.3 \%)$ & $<0.05$ \\
\hline$\geq 115$ & $49(16.2 \%)$ & $21(7.0 \%)$ & $28(9.3 \%)$ & $>0.05$ \\
\hline \multicolumn{5}{|l|}{$T G(m g / d L)$} \\
\hline$\leq 149$ & $246(81.5 \%)$ & $112(37.1 \%)$ & $134(44.3 \%)$ & $<0.05$ \\
\hline$\geq 150$ & $56(18.5 \%)$ & $19(6.3 \%)$ & $37(12.3 \%)$ & $<0.05$ \\
\hline \multicolumn{5}{|l|}{$B M I\left(\mathrm{~kg} / \mathrm{m}^{2}\right)$} \\
\hline$\leq 18.4$ & $1(0.3 \%)$ & $0(0 \%)$ & $1(0.3 \%)$ & - \\
\hline $18.5-24.9$ & $158(52.3 \%)$ & $70(23.2 \%)$ & $88(29.1 \%)$ & $>0.05$ \\
\hline $25.0-29.9$ & $111(36.8 \%)$ & $48(15.9 \%)$ & $63(20.9 \%)$ & $>0.05$ \\
\hline$\geq 30$ & $32(10.6 \%)$ & $13 \quad(4.3 \%)$ & $19(6.3 \%)$ & $<0.05$ \\
\hline \multicolumn{5}{|c|}{ Waist Circumference $(\mathrm{cm})$} \\
\hline$\leq 88$ & $121(40.1 \%)$ & $29(9.6 \%)$ & $92(30.5 \%)$ & $<0.05$ \\
\hline 89-102 & $71(23.5 \%)$ & $46(15.2 \%)$ & $25(8.3 \%)$ & $<0.05$ \\
\hline$\geq 103$ & $110 \quad(36.4 \%)$ & $56(18.5 \%)$ & $54(17.9 \%)$ & $>0.05$ \\
\hline \multicolumn{5}{|l|}{$S B P(m m H g)$} \\
\hline$\leq 139$ & 261 (86.4\%) & 116 (38.4\%) & 145 (48.0\%) & $<0.05$ \\
\hline$\geq 140$ & $41(13.6 \%)$ & $15(5.0 \%)$ & $26(8.6 \%)$ & $<0.05$ \\
\hline \multicolumn{5}{|l|}{$D B P(m m H g)$} \\
\hline$\leq 89$ & 259 (85.8\%) & $115(38.1 \%)$ & $144(47.6 \%)$ & $<0.05$ \\
\hline$\geq 90$ & $43(14.2 \%)$ & $16(5.3 \%)$ & $27(9.0 \%)$ & $<0.05$ \\
\hline
\end{tabular}

SBP is systolic blood pressure; DBP is diastolic blood pressure; TG is triglyceride; HDL is high density lipoprotein; LDL is low density lipoprotein; BMI is body mass index, $\mathrm{HbA}_{1 \mathrm{c}}$ is glycated hemoglobin.

Table 3. The distribution of cardiovascular risk factors' ratios (\%) between genders

\begin{tabular}{|c|c|c|c|c|}
\hline \multirow{2}{*}{ Risk Factors } & \multirow{2}{*}{ Total $(n=302)$} & \multicolumn{2}{|c|}{ Gender } & \multirow{2}{*}{ P-level } \\
\hline & & Male $(n=131)$ & Female ( $n=171)$ & \\
\hline Genetic predisposition & 109 (36.1\%) & $47(15.6 \%)$ & $62(20.5 \%)$ & $<0.05$ \\
\hline Hipodinamia & $161(53.3 \%)$ & $77(25.5 \%)$ & $84(27.8 \%)$ & $>0.05$ \\
\hline Smoking & $130(43.0 \%)$ & $73(24.2 \%)$ & 57 (18.9\%) & $>0.05$ \\
\hline Psychosocial factors (stress) & $174(57.6 \%)$ & $82(27.2 \%)$ & $9(3.0 \%)$ & $<0.05$ \\
\hline Overweight & $111(36.8 \%)$ & $48(15.9 \%)$ & $63(20.9 \%)$ & $<0.05$ \\
\hline Obesity & $32(10.6 \%)$ & $13(4.3 \%)$ & $19(6.3 \%)$ & $>0.05$ \\
\hline Abdominal obesity & $135(44.7 \%)$ & $56(18.5 \%)$ & $79(26.2 \%)$ & $<0.05$ \\
\hline Hyperglycemia & $9(3.0 \%)$ & $2(0.7 \%)$ & $7(2.3 \%)$ & $<0.05$ \\
\hline Hypertension & $38(12.6 \%)$ & $17(5.6 \%)$ & $21(7.0 \%)$ & $>0.05$ \\
\hline Tachycardia & $44(14.6 \%)$ & $18(6.0 \%)$ & $26(8.6 \%)$ & $>0.05$ \\
\hline
\end{tabular}

Participants having high value of blood pressure, hyperlipidemia, hyperglycemia, overweight, waist circumference which is above the normal range, and obesity were asked to consultation with a dietician.

\section{Discussion}

For successful prevention programs, several studies have suggested the importance of targeting young adults and identification of risk factors in this population [9-15]. Risk factors of CV diseases in young adults from various countries including 
Portugal [9], Columbia [10], Japan [11], Brazil [12], Chile [13], and Serbia $[14,15]$ has been reported.

Inspite of their high level of education, first year university students did not have better nutritional habits than the general population, as has been reported in other studies [16].

A prospective population-based Turkish Adult Risk Factor (TEKHARF) Study [17], a prevalence of metabolic syndrome in 3 out of 8 Turkish adults, Turks have low levels of total cholesterol (mean is $185 \mathrm{mg} / \mathrm{dl}$ ), LDL-cholesterol (mean is $116 \mathrm{mg} / \mathrm{dl}$ ), and $\mathrm{HDL}$-cholesterol (mean is 37 and $45 \mathrm{mg} / \mathrm{dl}$ in men and women). The latter is associated with comparatively high concentrations of triglycerides (mean $143 \mathrm{mg} / \mathrm{dl}$ ) and of apo B (mean is $115 \mathrm{mg} / \mathrm{dl}$ ). In TEKHARF study [17], it is remarkable that women exhibit identical LDL-cholesterol levels as men. Although our results are similar to TEKHARF Study [17], this study's main differences are young study population, and significant high mean triglyceride value especially in females.

Prevalence of cigarette smoking in Turkey is $33.4 \%$ for adults, and $6.9 \%$ for adults [18]. The prevalence of current smokers among university students in the present study was $43 \%$. In terms of both male (24.2\%) and female (18.9\%) students, we found a high smoking incidence regarding previous studies [19].

Obesity has become a worldwide phenomenon cutting across regional and economic barriers. Childhood and adolescent obesity has emerged as an epidemic in both the developed countries and developing countries [20].

A high proportion of university students in the present study were overweight. The prevalences of overweight and obesity (BMI $\geq 30$ ) in the present study were $36.8 \%$ and $10.6 \%$. The prevalences of overweight and obesity in a study done in North Carolina, USA among 582 students aged $18-25$ years were $21.3 \%$ and $10.8 \%$ [21].

The problem of obesity among university students is alarming. The high prevalence of overweight and obesity is probably due to the recent trend of male youths of eating fast food,

which is high in saturated fats, in restaurants, most of the days of the week, and the inadequate practice of physical activity [22].

Among men who were students at Glasgow University during 1948 to 1968 , a $10 \mathrm{mmHg}$ increase in systolic blood pressure measured at around age 20 years was associated with a $15 \%$ increased risk of cardiovascular mortality [23].

The prevalences of stage I hypertension (systolic blood pressure is $140-159 \mathrm{mmHg}$, diastolic blood pressure is $90-99$ $\mathrm{mmHg}$ ), in a large population study among 18,881 students aged with a mean of $18.4 \pm 1.8$ years were $2 \%$ [24]. The prevalence of stage I hypertension among university students in the present study was $12.6 \%$.

The striking results of this study are that smoking, and obesity are widespread among male and female university students in Northern Turkey. This must be considered in deterrent campaigns targeting this age group.

\section{Conclusion}

To prevent and reduce cardiovascular diseases in the young, further research should be carried out to develop more effective obesity, and smoking cessation programs.

Conflict of interest: none declared.

\section{Reference}

1. Haddad FH, Omari AA, Shamailah QM, et al. Lipid profile in patients with coronary artery disease. Saudi Med J 2002; 23: 1054-1058. (PMID: 12370711)

2. Wilund KR, Feeney LA, Tomayko EJ, Weiss EP, Hagberg JM. Effects of endurance exercise training on markers of cholesterol absorption and synthesis. Physiol Res 2009; 58: 545-552. (PMID: 18656998)

3. Kelley GA, Kelley KS. Effects of aerobic exercise on non-high-density lipoprotein cholesterol in children and adolescents: a meta-analysis of randomized controlled trials. Prog Cardiovasc Nurs 2008; 23: 128-132. (PMID: 19039893) (PMCID: PMC2596632) (doi: 10.1111/j.17517117.2008.00002.x)

4. Katcher HI, Hill AM, Lanford JL, Yoo JS, Kris-Etherton PM. Lifestyle approaches and dietary strategies to lower LDL-cholesterol and triglycerides and raise HDL-cholesterol. Endocrinol Metab Clin North Am 2009; 38: 45-78. (doi: 10.1016/j.ecl.2008.11.010) (PMID: 19217512)

5. Rodrigues AN, Perez AJ, Pires JG, et al. Cardiovascular risk factors, their associations and presence of metabolic syndrome in adolescents. J Pediatr (Rio J) 2009; 85: 55-60. (doi: 10.2223/JPED.1867) (PMID: 19198738)

6. Santos MG, Pegoraro M, Sandrini F, Macuco EC. Fatores de risco no desenvolvimento da aterosclerose na infância e adolescência. Arq Brás Cardiol 2008; 90: 301-308. (doi: 10.1590/S0066-782X2008000400012)

7. Perk J, De Backer G, Gohlke H, et al. The 2012 European guidelines on cardiovascular disease prevention in clinical practic (version 2012). Rev Esp Cardiol 2012; 65: 937.

8. National Institutes of Health. The Practical Guide to the Identification, Evaluation and Treatment of Overweight and Obesity in Adults. Bethesda, Maryland: National Institutes of Health, 2000.

9. Brandao MP, Pimentel FL, Silva CC, Cardoso MF. Risk factors for cardiovascular disease in a Portuguese university population. Rev Port Cardiol 2008; 27: 7-25. (PMID: 18447034)

10. Feliciano-Alfonso JE, Mendivil CO, Ariza ID, Perez CE. Cardiovascular risk factors and metabolic syndrome in a population of young students from the National University of Colombia. Rev Assoc Med Bras 2010; 56: 293-298. (doi: 10.1590/S0104-42302010000300012) (PMID: 20676535)

11. Furukawa $\mathrm{Y}$, Ehara N, Taniguchi $\mathrm{R}$, et al. Coronary risk factor profile and prognostic factors for young Japanese patients undergoing coronary revascularization. Circ J 2009; 73: 1459-1465. (PMID: 19531902) (doi: 10.1253/circj.CJ-08-1083)

12. Martins Mdo C, Ricarte IF, Rocha $\mathrm{CH}$, et al. Blood pressure, excess weight and level of physical activity in students of a public university. Arq Bras Cardiol 2010; 95: 192-199. (PMID: 20549132) (doi: 10.1590/S0066-782X2010005000069)

13. Palomo IF, Torres GI, Alarcon MA, Maragano PJ, Leiva E, Mujica V. High prevalence of classic cardiovascular risk factors in a population of university students from south central Chile. Rev Esp Cardiol 2006; 59 : 1099-1105. (PMID: 17144984)

14. Stojanovic D, Visnjic A, Mitrovic V, Stojanovic M. Risk factors for the occurrence of cardiovascular system diseases in students. Vojnosanit Preg/ 2009; 66: 453-458. (PMID: 19583143)

15. Sporisevic L, Krzelj V, Bajraktarevic A, Jahic E. Evaluation of cardiovascular risk in school children. Bosn J Basic Med Sci 2009; 9: 182-186. (PMID: 19754470)

16. Schulze MB, Hoffmann K, Kroke A, Boeing $H$. Dietary patterns and their association with food and nutrient intake in the European Prospective Investigation into Cancer and Nutrition (EPIC)-Potsdam study. $\mathrm{Br} \mathrm{J}$ Nutr 2001; 85: 363-373. (PMID: 11299082) (doi: 10.1079/BJN2000254)

17. Onat A. Lipids, lipoproteins and apolipoproteins among turks, and impact on coronary heart disease. Anadolu Kardiyol Derg 2004; 4: 236245. (PMID: 15355827) 
18. WHO Report on the Global Tobacco Epidemic, 2009: Implementing smoke-free environments, The MPOWER package. World Health Organization. France, 2009.

19. Korzeniowska K, Cieślewicz A, Szałek E, Jabłecka A. Attitudes of pharmacy and dentistry students of Poznan Medical University towards smoking. Przegl Lek 2012; 69: 1053-1054. (PMID: 23421090)

20. Lakshman R, Elks CE, Ong KK. Childhood obesity. Circulation 2012; 126 : 1770-1779. (doi: 10.1161/CIRCULATIONAHA.111.047738) (PMID: 23027812)

21. Sira N, Pawlak R. Prevalence of overweight and obesity, and dieting attitudes among Caucasian and African American college students in Eastern North carolina: A cross-sectional survey. Nutr Res Pract 2010; 4: 36-42. (doi: 10.4162/nrp.2010.4.1.36) (PMCID: PMC2830413) (PMID: 20198207)

22. Sabra AA, Taha AZ, Al-Sebiany AM, Al-Kurashi NY, Al-Zubier AG. Coronary heart disease risk factors: prevalence and behavior among male university students in Dammam City, Saudi Arabia. J Egypt Public Health Assoc 2007; 82: 21-42. (PMID: 18217323)

23. McCarron P, Okasha M, McEwen J, Davey Smith G. Blood pressure in early life and cardiovascular disease mortality. Arch Intern Med 2002; 162: 610-611.

24. Gray L, Lee IM, Sesso HD, Batty GD. Blood pressure in early adulthood, hypertension in middle age, and future cardiovascular disease mortality: HAHS (Harvard Alumni Health Study). J Am Coll Cardiol 2011; 58: 2396-2403. (doi: 10.1016/j.jacc.2011.07.045) (PMID: 22115646) (PMCID: PMC3253414)

Authors:

Rasim Kutlu - MD, Department of Cardiology, Gümüşhane State Hospital, Gümüşhane, Turkey;

Mehmet Erdem Memetoglu - MD, Department of Cardiovascular Surgery, Siyami Ersek Educating and Training Hospital, Istanbul, Turkey. 